SANTOS, Francisco Edvander Pires. Gestão de acervos audiovisuais em repositórios. Orientação: Maria Giovanna Guedes Farias. Coorientação: Luiz Tadeu Feitosa. 2018. 194 f. Dissertação (Mestrado em Ciência da Informação) - Programa de Pós-Graduação em Ciência da Informação, Centro de Humanidades, Universidade Federal do Ceará, Fortaleza, 2018. Disponível em: http://www.repositorio.ufc.br/handle/riufc/39305. Acesso em: 25 set. 2019 .

\title{
GESTÃO DE ACERVOS AUDIOVISUAIS EM REPOSITÓRIOS
}

\author{
THE MANAGEMENT OF AUDIOVISUAL COLLECTIONS ON DIGITAL REPOSITORIES
}

\section{RESUMO}

Apresenta resultados de pesquisa cujo objetivo se constituiu em construir critérios e diretrizes para a gestão de imagens em movimento e acervos sonoros produzidos na Universidade Federal do Ceará (UFC), uma proposição realizada a partir da mediação bibliotecária na estruturação de um repositório audiovisual. Como aporte teórico, discutem-se as dimensões da informação audiovisual; a competência e mediação bibliotecária na gestão de acervos audiovisuais; e as diretrizes nacionais e internacionais para gestão de repositório audiovisual. Trata-se de uma pesquisa qualitativa, que recorre à triangulação metodológica visando contemplar a amplitude do tema proposto. Como primeiro método de pesquisa, utiliza a pesquisa documental para análise dos documentos normativos que regem os repositórios institucionais de universidades e institutos de pesquisa brasileiros, selecionados sob o critério dos que mais se destacaram no Ranking Web of Repositories, na finalidade de verificar se essas políticas e repositórios contemplam, de alguma forma, os acervos audiovisuais. 0 segundo método adotado foi a análise de conteúdo, que possibilitou a categorização e análise de uma amostra dos acervos audiovisuais produzidos na UFC, dentre eles: documentários; curtas-metragens; animações; programas de televisão; programas de rádio; podcasts; videoaulas; palestras; e espetáculos musicais. A fim de proceder com a análise e descrição dessa amostra, houve a necessidade de criação de um instrumento para coleta de dados, construído no software Evernote e compartilhado no repositório Zenodo. Os dados foram coletados no software de acordo com o corpus selecionado para cada ambiente de pesquisa, quais sejam: Curso de Jornalismo da UFC; Casa Amarela Eusélio Oliveira; Programa UFCTV; Rádio Universitária FM; Biblioteca de Ciências Humanas; e Coral da UFC. A escolha dos ambientes corresponde à amostra selecionada para esta pesquisa, representando os tipos de acervos audiovisuais categorizados na análise de conteúdo. Para descrição dos dados coletados, foi utilizada a técnica de decupagem, que permite o detalhamento do que é assistido nas imagens e ouvido nos áudios analisados, além da atribuição de palavraschave que representam o conteúdo audiovisual. Como análise e discussão dos resultados, apresentam-se a análise dos documentos que regem o funcionamento dos repositórios institucionais; a análise das categorias de acervos audiovisuais produzidos na UFC; e os critérios e diretrizes estabelecidos para repositório audiovisual. Definiram-se elementos 
que conduziram à proposta dos critérios e das diretrizes para gestão das coleções em repositório audiovisual no software DSpace, a saber: desenvolvimento de acervos audiovisuais; definição de metadados; decupagem e indexação; e ciclo de produção audiovisual, fluxo de submissão e designação de responsabilidades. Conclui que os critérios e diretrizes propostos fornecem subsídios informacionais para gestão de imagens em movimento e acervos sonoros em repositório audiovisual no DSpace e que podem ser aplicados em todos os ambientes produtores de informação audiovisual, e não apenas no ambiente universitário.

Palavras-chave: Gestão da informação. Acervos audiovisuais. Mediação bibliotecária. Decupagem. Repositório audiovisual.

\section{ABSTRACT}

This master's thesis presents the results of a research that focusing on proposing criteria and guidelines to manage moving images and sound collections, which have been produced at a public university in Brazil, named Universidade Federal do Ceará (UFC). It is a proposal made from the librarian's mediation at setting up an audiovisual repository. As a theoretical contribution, we discuss the dimensions of audiovisual information, the librarian's competence and mediation at managing audiovisual collections, and some Brazilian and international guidelines for managing audiovisual repository. It is characterized as a qualitative research through methodological triangulation, which is proposed to explain the breadth of the subject. The first research method is the documentary research for analyzing normative documents that rule the institutional repositories of ten Brazilian universities and research institutions, which were selected under the criterion of those that stood out most on the Ranking Web of Repositories, aiming to verify if those documents have pointed out audiovisual collections in their scope. The second research method is the content analysis, which enabled the categorization and analysis of a sample of the audiovisual collections produced at UFC, such as: documentaries; short films; animations; television programs; radio programs; podcasts; video classes; lectures; and musical concerts. After that, a data collection tool was constructed on Evernote to analyze and describe that sample of audiovisual productions, and then the data was shared on Zenodo, which is an online repository. The data were collected according to the corpus selected for each research environment at UFC, namely: a course of Journalism; a school of cinema; a television program called UFCTV; an academic radio station; an academic library; and an academic choir. The choice of these environments is related to the sample for analyzing and describing. The analysis and description were made based on the types of audiovisual collections categorized from the content analysis method and through the audiovisual description technique, which allows to describe in detail all that is seen on the moving images and also which is heard from the sound analyzed, besides represent the audiovisual content by keywords. The section on discussion of the results is compounded by the analysis of ten normative documents on Brazilian institutional repositories; by the analysis of each category of audiovisual collections produced at UFC; and by our criteria and guidelines to manage audiovisual repository on DSpace, which were set up from communities, collections, metadata, audiovisual description and indexing, and a proposal of workflow at producing 
audiovisual information. Finally, we conclude that the development of our criteria and guidelines provides informational resources for managing moving images and sound collections on online repositories, also considering that each criterion and guideline can be applied at all kind of environments which have produced audiovisual information, and not only in public universities.

Keywords: Information management. Audiovisual collections. Librarian's mediation. Audiovisual description. Audiovisual repository.

\section{SOBRE O AUTOR}

\section{Francisco Edvander Pires Santos}

Mestre pelo Programa de Pós-Graduação em Ciência da Informação da Universidade Federal do Ceará (UFC). Bibliotecário na Biblioteca de Ciências Humanas da UFC. Membro da International Association of Sound and Audiovisual Archives (IASA).

E-mail: edvanderpires@gmail.com

\section{ACESSO ABERTO}

Copyright: Esta obra está licenciada com uma Licença Creative Commons Atribuição 4.0 Internacional. $(\mathrm{cc}) \mathrm{EY}$

Financiamento: Não há.

Recebido em: 29/09/2019.

Aceito em: 29/09/2019.

Revisado em: 13/10/2019.

Como citar este resumo:

SANTOS, Francisco Edvander Pires. Gestão de acervos audiovisuais em repositórios. Informação em

Pauta, Fortaleza, v. 4, n. 2, p. 196-198, jul./dez. 2019. DOI: 10.32810/2525-3468.ip.v4i2.2019.42263.196$\underline{198 .}$ 